\title{
高温養生下におけるフライアッシュコンクリートの力学特性 \\ MECHANICAL PROPERTIES OF CONCRETE WITH FLY ASH UNDER HIGH TEMPERATURE CURING
}

\author{
長瀧重義*·大賀 宏行**・坂井悦 郎*** \\ By Shigeyoshi NAGATAKI, Hiroyuki OHGA and Etsuro SAKAI
}

\begin{abstract}
Compressive strength and creep behaviour of concrete with fly ash under steam and autoclave curing are evaluated with regard to the hydration between cement and fly ash. Concrete with $40 \%$ fly ash replacement shows almost the same compressive strength as concrete without fly ash under autoclave curing. Compressive strength can be increased by proper curing conditions in steam and autoclave curing. Reduction of water-binder ratio by use of a large amount of superplasticizer and use of fly ash classified by sieve under specified diameter are effective for improving compressive strength. Creep of concrete with $40 \%$ fly ash replacement is as same as that of concrete without fly ash during autoclave curing.
\end{abstract}

Keywords : fly ash, curing, compressive strength, creep, micro structure

\section{1. まえがき}

コンクリート用混和剤としてフライアッシュを用いる と, コンクリートの流動性の改善, 水和熱の低減, 長期 強度の増大, アルカリ骨材反応の抑制等, 数多くの利点 を有しており, 水理構造物等に広く利用されている. 一 方，フライアッシュ自体は反応性が低いため，初期にお ける強度が低いこと, 含有炭素が $\mathrm{AE}$ 剂を吸着するこ とから所要の空気量を連行するのに必要な $\mathrm{AE}$ 剂量が 増大すること等の問題点も指摘されている11. 現在, フ ライアッシュは全発生量の半分以上が廃棄されてお $\eta^{2)}$, 今後の発生量の増大に対応してフライアッシュの 多量利用法の開発が望まれている.さらに, 海外炭の利 用が増大するものと予想されるが, 海外炭は国内炭と化 学成分が異なることから, 副産されるフライアッシュの 品質も国内炭とは異なっている ${ }^{3), 4)}$. また, 環境規制に よる炉内燃焼温度の制限などにより, フライアッシュの 品質が変動する可能性もあることから, これらのフライ

\footnotetext{
* 正会員 工博 東京工業大学教授 工学部土木工学科 ( $\mathrm{T} 152$ 目黒区大岡山 2-12-1)

** 正会員 工修 東京工業大学助手 工学部土木工学科 (同上)

*** 工博 電気化学工業 (株) 中央研究所 ( ₹ 194 町田市旭町 3-5-1)
}

アッシュの品質を把握し, コンクリート用混和材として の適用性, さらにはフライアッシュの多量利用法につい て検討を加える必要がある.

そこで本研究は, 近年国内炭および海外炭から副産さ れる多種のフライアッシュの物理化学的性質について検 討を加えるとともに, フライアッシュとセメントの反応 が高温において活発になることに着目し, フライアッ シュを多量に混和したコンクリートの蒸気養生後および オートクレーブ養生後の圧縮強度特性について, 微細組 織と関連させ検討を加えた.

\section{2. 実 験 概 要}

\section{（1）使用材料}

本研究では, 普通ポルトランドセメントおよび試験用 にサンプリングしたクラス F フライアッシュ (43 種) を用いた. フライアッシュの物理化学的性質を表一1に 示す. 骨材は, 川砂および砕石を用いた. ナフタレンス ルホン酸ホルマリン高縮合物を主成分とする高性能娍水 剤を用いた。

\section{(2) 配 合}

コンクリートの配合においては, 単位結合材量を 450 $\mathrm{kg} / \mathrm{m}^{3}$, 高性能減水剤の添加率を結合材量に対し固形分 で $0.5 \%$ （一部 $1.0 \%$ まで増大させた）一定とし, フ 
ライアッシュの置換率を $0 \%$ から $60 \%$ まで変化させ, スランプが $8 \pm 1 \mathrm{~cm}$, 空気量が non $\mathrm{AE}, 2.0$ および 4.0 \% となるように単位水量および $\mathrm{AE}$ 剂量を変化させた. モルタルの場合, 砂セメント比を 2.0 , 高性能減水剂の 添加率を結合材量に対し固形分で $0.5 \%$ 一定とし, フ ライアッシュの置換率を $0 \%$ から $50 \%$ まで変化させ, フローが $200 \pm 5$ となるように水結合材比を決定した.

\section{（3）養生条件}

コンクリートを打設し， 4 時間の前置きを行ったあと， 蒸気養生を開始した. 昇温速度を $20^{\circ} \mathrm{C} / \mathrm{h}$ 一定とし, 最 高温度を $65^{\circ} \mathrm{C}$ および $80^{\circ} \mathrm{C}$, 最高温度保持時間を 3 時間, 4.5 時間, 5.89 時間および 6 時間とした. 蒸気養生後直 ちにオートクレーブ養生を行った. 昇温速度 $60^{\circ} \mathrm{C} / \mathrm{h}$, 最高温度保持時間を 5 時間一定とし，最高温度を 150 , 180,190 および $210^{\circ} \mathrm{C}$ と変化させた.

\section{(4) 压縮強度}

圧縮強度は, 水中養生材令 28 日後, 蒸気養生直後お よび蒸気養生に続いてオートクレーブ養生を行った直後 （以下オートクレーブ養生直後とする）において実施し た.

\section{（5）微細組織の検討}

コンクリートと同一の水結合材比およびフライアッ シュの置換率を有し，コンクリートと同一の養生条件を 施したペーストを作成し，試料とした．粉末 X 線回折
法による水和生成物の同定，電子顕微鏡による微細組織 の観察，水置換法による空隙量の測定，水銀圧入法によ る細孔径分布と細孔量の測定および窒素吸着法による比 表面積の測定を行い，ペーストの微細組織およびフライ アッシュの反応性について検討を加えた．水置換法によ る空隙量は次式を用いて算出した5).

$$
\begin{gathered}
p=\left(W_{h}-W_{d}\right) /\left(W_{h}-W_{w}\right) \times 100(\%) \\
\text { ただし }, W_{h}: \text { 試料の表乾重量 } \\
W_{d}: 105^{\circ} \mathrm{C} \text { で一定重量となるまで乾燥させた } \\
\text { 試料の重量 } \\
W_{w}: \text { 試料の水中重量 }
\end{gathered}
$$

（6）フライアッシュの分級

ふるい目が $25 \mu \mathrm{m}, 42 \mu \mathrm{m}, 82 \mu \mathrm{m}$ のふるいを用い, 風ふるい機によりフライアッシュを各粒径範囲に分級し た.

\section{3. フライアッシュのキャラクタリゼーション}

\section{（1）フライアッシュの化学的性質}

強熱減量は $\mathrm{AE}$ 剤を吸着する炭素の量に比例するが, 石炭の種類, 石炭の粉砕の程度, 炉内燃焼温度などに影 響を受ける.今回用いたフライアッシュの強熱減量は

\begin{tabular}{|c|c|c|c|c|c|c|c|c|c|c|c|c|c|}
\hline & & 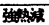 & $\mathrm{SiO}_{2}$ & $\mathrm{Al}_{2} \mathrm{O}_{3}$ & $\mathrm{Pe}_{2} \mathrm{O}_{3}$ & $\mathrm{CaO}$ & 全ガラス & & 密加さ & 比褩面䖽 & 単位水量 & \multicolumn{2}{|c|}{ 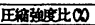 } \\
\hline (6) & 石媒の有地 & $+\infty$ & $\infty$ & $\infty$ & $\infty$ & $\infty$ & 量 & 比重 & 比留 & $(\mathrm{c} / \mathrm{k} / \mathrm{g})$ & 比 $\infty$ & 288 & 918 \\
\hline 7ライフォシュ1 & 旦本 & 1.5 & 51.6 & 27.6 & 5.3 & 8.8 & 63.9 & 2.17 & 1.37 & 2900 & 98 & 77.2 & 88.0 \\
\hline フライフンะ2 & 旦本 & 8.2 & 54.2 & 24.5 & 5.2 & 5.4 & 55.9 & 2.10 & 1.26 & 3000 & 100 & 73.3 & 76.2 \\
\hline フラ17ンシะ3 & 日本 & 1.4 & 61.4 & 24.2 & 4.8 & 2.3 & 57.1 & 2.10 & 1.23 & 3420 & 97 & $\pi 7.5$ & 92.6 \\
\hline フライフォシュ4 & & 4.4 & 51.6 & 26.2 & 5.7 & 6.3 & 63.3 & 2.22 & 1.42 & 2910 & $\frac{9}{9}$ & 74.9 & 87.3 \\
\hline フライアンジ 5 & 㝵本 & 2.4 & 55.3 & 28.2 & 5.2 & 5.3 & 62.6 & 2.18 & 1.44 & 3240 & $\frac{9}{7}$ & 83.7 & \\
\hline フร17ーシ×6 & 本 & 6.8 & 54.3 & 28.1 & 6.3 & 5.8 & 63.3 & 2.14 & 1.20 & 2720 & 99 & 69.5 & - \\
\hline フライフッシะ7 & 昌本 & 2.7 & 53.7 & 25.9 & 5.0 & 7.5 & 63.3 & 2.17 & 1.36 & 3240 & & $\underline{-}$ & $=$ \\
\hline $7517 ン シ ニ 8$ & 旦本 & 1.6 & 52.6 & 26.4 & 5.0 & 7.4 & 63.2 & 2.22 & 1.38 & 3170 & 95 & $=$ & \\
\hline フライフォシェ9 & 日本 & 2.7 & 52.5 & 26.4 & 5.0 & 7.4 & 62.5 & 2.25 & 1.40 & 370 & $\frac{9}{21}$ & $=$ & $=$ \\
\hline フライフンシュ10 & 本 & 4.6 & 50.1 & 25.5 & 6.2 & 6.3 & 64.8 & 2.25 & 1.34 & 3150 & 98 & $=$ & $=$ \\
\hline フライアッシュ11 & 本 & 4.5 & 49.2 & 25.0 & 6.0 & 6.5 & 56.9 & 2.20 & 1.22 & 279 & 97 & & \\
\hline フライアンシュ12 & 本 & 8.8 & 48.2 & 23.8 & 6.2 & 6.8 & 50.4 & 2.17 & 1.19 & 3190 & 99 & $=$ & - \\
\hline フライアッシュ13 & 本 & 2.5 & 53.7 & 25.9 & 5.0 & 7.5 & - & 2.17 & & & - & & - \\
\hline フライアッシュ14 & 日本 & 2.5 & 55.3 & 28.2 & 5.2 & 5.3 & $=$ & 2.18 & 1.47 & 3950 & 97 & 83.7 & 102.3 \\
\hline フライフォシェ 15 & 本 & 4.6 & 57.0 & 27.2 & 5.5 & 4.3 & $=$ & 2.23 & 1.38 & 411 & 98 & 86.0 & 105.3 \\
\hline フライフォシニ 16 & & 7.0 & 54.3 & 28.1 & 6.3 & 5.8 & & 2.14 & 1.37 & 3310 & 99 & 69.5 & 88.5 \\
\hline フライアッシュ17 & WHD & 4.6 & 58.1 & 34.1 & 2.3 & 0.5 & 47.3 & 2.17 & 1.04 & 500 & 101 & 75.8 & 79.4 \\
\hline フンシニ18 & 5 & 11.3 & 57.5 & 34.4 & 1.4 & 0.3 & 35.0 & 2.08 & 0.94 & 518 & 102 & 77.2 & $\pi .9$ \\
\hline $7 \% シ=19$ & 5 & 7.2 & 74.4 & 18.5 & 2.1 & 0.7 & 63.0 & 2.09 & 0.98 & 410 & 102 & 72.4 & 75.8 \\
\hline フライフッシュ20 & 5 & 2.0 & 67.0 & 21.0 & 3.4 & 2.9 & 49.5 & 2.09 & 0.96 & $\frac{272}{447}$ & 102 & 74.2 & 84.9 \\
\hline フライアンシะ21 & STHA & 2.5 & 68.7 & 20.4 & 3.9 & 2.3 & 59.7 & 2.07 & 0.96 & 3890 & 102 & 69.1 & 76.9 \\
\hline フライフォシュ22 & stits & 4.2 & 64.9 & 20.5 & 3.9 & 2.9 & 53.2 & 2.02 & 1.0 & 337 & 102 & 68.9 & 72.4 \\
\hline & & 6.2 & & 20.3 & & 2.9 & 57.2 & 2.04 & 1.0 & 355 & 101 & 66.1 & 71.0 \\
\hline $7>シ=24$ & H(B) & 7.3 & 62.9 & 19.4 & 4. & & 55.7 & 2.04 & 1.0 & 38 & 101 & 64.0 & 68.1 \\
\hline 7 7ン =25 & $H(0)$ & 3.4 & 64.9 & 27.8 & 1.9 & 0.5 & 44.0 & 2.05 & 1.13 & 310 & 100 & 68.2 & 75.8 \\
\hline $7 \because シ=26$ & 南了 & 2.0 & 43.5 & 34.6 & 5.8 & 9.9 & 34.9 & 2.31 & 1.00 & 479 & 102 & 73.1 & 77.3 \\
\hline フライフンシュ27 & 南7 & 5.4 & 42.3 & 33.8 & 5.6 & $\frac{10.0}{10.0}$ & 37.3 & 2.25 & 1.2 & 3550 & 101 & 68.7 & 71.4 \\
\hline 7 ×*28 & उष & 6.6 & 41.4 & 34.1 & & 9.8 & 45.0 & 2.18 & & 4510 & 102 & 65.7 & \\
\hline フ5イフンシะ29 & 南下 & 9.8 & 39.8 & 32.0 & $\frac{7.2}{5.2}$ & 10.0 & 35.8 & 2.19 & 1.07 & 4200 & 102 & 0.2 & 67.8 \\
\hline フライフンシニ30 & 南下(2) & 3.2 & 46.1 & 32.3 & & 7.1 & 45.0 & 2.27 & 1.06 & 4580 & 101 & 68.0 & 76.7 \\
\hline フライナッシュ31 & 南下(2) & 4.5 & 40.8 & 32.1 & 5.3 & 7.9 & 40.8 & $\frac{2.25}{2.25}$ & 1.00 & 5510 & 103 & 68.9 & 91.0 \\
\hline Tッシ $=32$ & 南下(2) & 6.6 & 44.0 & 30.9 & 5 & 8.5 & 42.4 & 2.20 & 1.08 & 3980 & 101 & 68.2 & 72.4 \\
\hline フライファシュ33 & 筒了(2) & 7.9 & 43 & 30.8 & 5.6 & & 39.0 & 2.21 & & 435 & 101 & 66.8 & 75.0 \\
\hline フライファシュ34 & 中国 & 2.7 & 49.8 & 21.4 & 16.6 & 5.2 & 41.8 & 2.46 & 1.24 & 4540 & 101 & 75.4 & 73.0 \\
\hline フライフォシะ35 & 中国 & & & & & & 42.0 & & & & & 75.2 & 79 \\
\hline フライフンシニ36 & 中国 & 6.8 & \begin{tabular}{ll|}
47.8 \\
\end{tabular} & 20.1 & 17.1 & 4.5 & 47.5 & 2.40 & 1.26 & 4200 & 101 & 66.6 & 74.4 \\
\hline フ51フッシะ37 & 中国 & 7.8 & 47.0 & 20.4 & 16.7 & 4.6 & & & & 4700 & 101 & 70.5 & \\
\hline フライフォシュ38 & $10+\infty(6)$ & 3.1 & 60.0 & 24.1 & 5.6 & & 60.0 & 2.28 & & & 9 & 77.7 & \\
\hline フライファシニ39 & 南下+中 & 4.0 & 43.3 & 31. & 7.8 & 8.8 & 38.6 & 2.31 & 1.0 & 489 & 101 & 71.7 & 83.2 \\
\hline フライフォシ×40 & 南万+中 & 6.1 & & & 10.4 & & 43.4 & & & $\frac{40}{348}$ & 10 & 63.8 & \\
\hline フライフンシュ41 & 南 $7 @+$ +中 & 8.2 & 44.6 & 28.0 & 9.3 & 7.1 & 43.1 & 2.33 & 1.14 & 4650 & 100 & 74.2 & 74.4 \\
\hline フライフンシュ42 & 甫了(2)+中 & 7.5 & 46.8 & 25.1 & 11.3 & 5.8 & 35.6 & 2.26 & 1.1 & 4010 & 102 & 65.4 & 72.2 \\
\hline フ5イフォシュ43 & 南下(2)+中 & 9.4 & 45.1 & 24.7 & 11.4 & 5.7 & 39.3 & 2.27 & 1.1 & 4530 & 102 & 68.0 & 11.8 \\
\hline
\end{tabular}
1.4 から，JIS の規格值である $5 \%$ を越えて $11.3 \%$ ま で広範囲にわたっている．コンクリートに用いた場合， 所要の空気量を連行するのに必要な $\mathrm{AE}$ 剤量もフライ

表一1 フライアッシュの物理化学的性質 
表一2 分級したフライアッシュの物理化学的性質

\begin{tabular}{|c|c|c|c|c|c|c|c|c|c|c|}
\hline 理 & 柱经の䫏用 & 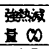 & $\begin{array}{l}\mathrm{SiO}_{2} \\
\mathrm{C}\end{array}$ & $\begin{array}{c}\mathrm{Al}_{2} \mathrm{O}_{3} \\
(0)\end{array}$ & $\begin{array}{c}\mathrm{Fe}_{2} \mathrm{O}_{3} \\
\infty\end{array}$ & $\begin{array}{l}c_{20} \\
\infty\end{array}$ & 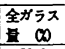 & 比值 & 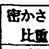 & $\begin{array}{l}\text { 戦位水量 } \\
\text { 比 }\end{array}$ \\
\hline \multirow{7}{*}{ フライアンシュ1 } & 末 分 制 & 1.5 & 51.6 & 27.6 & 5.3 & 8.8 & 63.9 & 2.17 & 1.37 & 97.5 \\
\hline & $82 \mu$ 以上 & 3.6 & 54.2 & 26.6 & 4.3 & 6.7 & 57.1 & 1.95 & 0.90 & 120.1 \\
\hline & \begin{tabular}{|l|}
$42 \sim 82 \mu \mathrm{m}$ \\
\end{tabular} & 1.6 & 54.0 & 26.5 & 4.6 & 8.0 & 58.3 & 2.02 & 1.01 & 103.6 \\
\hline & $25 \sim 42 \mu \mathrm{m}$ & 1.1 & 50.4 & 26.1 & 5.2 & 8.8 & 50.6 & 2.16 & 1.18 & 96.2 \\
\hline & $82 \mu \mathrm{m}$ 以下 & 1.4 & 49.2 & 26.5 & 5.9 & 8.8 & 62.1 & 2.26 & 1.43 & 92.9 \\
\hline & $42 \mu \mathrm{m}$ И下 & 1.4 & 51.3 & 26.8 & 5.8 & 9.6 & 60.2 & 2.31 & 1.45 & 92.3 \\
\hline & $25 \mu \mathrm{m}$ ए人 & 1.4 & 49.3 & 26.5 & 5.9 & 9.4 & 66.3 & 2.40 & 1.42 & 89.9 \\
\hline \multirow{7}{*}{ フライフッシュ28 } & 未分級 & 9.5 & 41.4 & 34.1 & 4.1 & 9.8 & 45.0 & 2.18 & 1.09 & 105.0 \\
\hline & $82 \mu \mathrm{m}$ 以上 & 8.6 & 43.4 & 21.1 & 8.3 & 14.2 & 23.4 & 2.22 & 1.03 & \\
\hline & $42 \sim 82 \mu \mathrm{m}$ & 9.8 & 37.5 & 25.2 & 6.6 & 15.5 & 39.0 & 2.19 & 0.96 & 110.9 \\
\hline & $25 \sim 42 \mu \mathrm{m}$ & 10.3 & 38.2 & 28.4 & 5.9 & 13.5 & 35.7 & 2.18 & 1.00 & 108.0 \\
\hline & $82 \mu$ 以ू下 & 6.7 & 39.4 & 31.2 & 4.1 & 10.0 & 34.6 & 2.21 & 1.2 & 100.0 \\
\hline & $42 \mu \mathrm{m}$ घ & 6.4 & 39.8 & 31.8 & 4.0 & 9.8 & 41.9 & 2.23 & 1.21 & 97.6 \\
\hline & $25 \mu=$ 以下 & 5.4 & 41.4 & 34.2 & 3.0 & 7.5 & 42.3 & 2.28 & 1.18 & 95.6 \\
\hline \multirow{4}{*}{ フライアンシニ25 } & 未分钑 & 3.5 & 64.9 & 27.8 & 1.9 & 0.5 & 44.0 & 2.05 & 1.13 & \\
\hline & $82 \mu$ 以ล下 & 3.4 & 63.1 & 25.8 & 2.1 & 0.4 & 37.7 & 2.07 & 1.19 & \\
\hline & $42 \mu 0$ ए人下 & 3.4 & 62.9 & 26.4 & 1.7 & 0.4 & 45.9 & 2.13 & 1.18 & \\
\hline & $25 \mu \mathrm{m}$ 以下 & .3 .0 & 63.4 & 26.8 & 1.5 & 0.4 & 52.4 & 2.15 & 1.18 & \\
\hline \multirow{4}{*}{ フライフンシュ17 } & 末分級 & 11.4 & 58.1 & 34.1 & 2.3 & 0.5 & 35.3 & 2.08 & 1.04 & \\
\hline & $82 \mu m$ 以下 & 12.1 & 53.2 & 29.6 & 1.8 & 0.3 & 33.8 & 2.08 & 1.01 & \\
\hline & $42 \mu \mathrm{m}$ 以下下 & 6.5 & 55.5 & 32.6 & 1.6 & 0.3 & 44.5 & 2.14 & 1.07 & \\
\hline & $25 \mu=$ 以ू下 & 6.3 & 55.3 & 34.3 & 1.7 & 0.4 & 45.1 & 2.17 & 1.07 & \\
\hline \multirow{3}{*}{ フライフッシニ2 } & 未分制 & 8.3 & 54.2 & 24.5 & 5.2 & 5.4 & 55.9 & 2.10 & 1.26 & 103.6 \\
\hline & $82 \mu$ ए人下 & 7.2 & 50.9 & 2.9 & 6.0 & 5.6 & 49.8 & 2.15 & 1.28 & 96.2 \\
\hline & $25 \mu \mathrm{n}$ 以下 & 6.6 & 51.2 & 23.9 & 6.0 & 5.6 & 58.3 & 2.05 & 1.28 & 95.6 \\
\hline
\end{tabular}

アッシュの種類により大きく異なり, ほぼ強熱減量に比 例している。

化学成分に関しては, 石炭の種類によって各成分の含 有割合が異なる傾向を示している．たとえば，オースト ラリア産の石炭から産するフライアッシュは, $\mathrm{SiO}_{2}$ 量 が多く, $\mathrm{CaO}$ 量が少ない. 南アフリカ産の石炭から産 するフライアッシュは比較的 $\mathrm{SiO}_{2}$ 量が少なく, $\mathrm{CaO}$ 量 が多く, 中国産のものは $\mathrm{Fe}_{2} \mathrm{O}_{3}$ 量が多くなっている. 全ガラス量 (ガラス質の $\mathrm{SiO}_{2}$ 量, $\mathrm{Al}_{2} \mathrm{O}_{3}$ 量および $\mathrm{Fe}_{2} \mathrm{O}_{3}$ 量の和）は国内炭のものが最も多く含まれている が，化学成分と同様にオーストラリア産の石炭から産す るフライアッシュも他に比べて多く含まれている.

表一2に分級したフライアッシュの物理化学的性質を 示す. 強熱減量の粒径による差異について検討を加える と, 既往の研究6) と同様に粒径が小さいほど強熱減量が 小さな值を示している. したがって，ふるいにより比較 的粒径の大きいものを除去することにより, 強熱減量を 低減することが可能である．また，粒径の小さなフライ アッシュほど, 冷却速度が速いため7), 全ガラス量も強 熱減量と同様に粒径の小さなフライアッシュほど多く含 まれている.

\section{（2）フライアッシュの物理的性質}

比重は, 南アフリカおよび中国産の石炭から産するフ ライアッシュが日本およびオーストラリア産のものに比 ベ比較的大きな值を示している.

電子顕微鏡による観察によると, 粒子の形状はフライ アッシュの種類により大きく異なっているが, モルタル の単位水量比は 95〜103\% 程度の範囲にあり, 大きな 差は生じていない.これは, モルタルの水セメント比が 大きいこと, フライアッシュの置換率が小さいことおよ び単位水量比を求める際に比重の影響を考慮したために 単位水量比に大きな差が生じなかったものと考えられ る. 実際に, コンクリートにフライアッシュを混和した
場合には，4. で述べるようにフライアッシュの種類に より単位水量は大きく異なる結果となった.

電子顕微鏡による観察によれば粒子形状も粒径により 異なり, 粒径が小さいほど球形粒子の割合が多くなり, 特に $25 \mu \mathrm{m}$ 以下の粒子はほとんどが球形であった.し たがって, 単位水量比も粒径が小さいほど小さくなり, たとえばフライアッシュ 28 の単位水量比は未分級で $105 \%$ であるのに対し， $25 \mu \mathrm{m}$ 以下では $95.6 \%$ と減水 効果を示し, モルタルの圧縮強度も著しく増大した.

\section{4. 高温養生下におけるフライアッシュの反応 性}

\section{（1）コンクリートの強度特性}

3.において, フライアッシュは種類によりその物理 化学的性質が異なることが明らかとなった. 本節ではフ ライアッシュの反応性に高温養生が有効であることに着 目し, 蒸気養生およびオートクレーブ養生後の強度特性 について検討を加えた。

図一1 はフライアッシュ 13 を用いたコンクリート (non $\mathrm{AE}$ ) の水中 28 日養生後, 蒸気養生直後および オートクレーブ養生直後の圧縮強度とフライアッシュの 置換率との関係を示す. 水中養生 28 日程度ではポゾラ ン反応があまり進んでいないため, コンクリートの圧縮 強度はフライアッシュの置換率の増加とともに減少して いる. また, 蒸気養生直後では水中養生 28 日後の場合 に比べ置換率の増加に伴う圧縮強度の低下量は少ないも のの, やはりコンクリートの圧縮強度はフライアッシュ の置換率の増加とともに減少している. 一方, 蒸気養生 後にオートクレーブ養生を行った供試体の王縮強度は, フライアッシュの置換率が $25 \%$ までは置換率の増加と ともに減少するが, その後増大し置換率が $40 \%$ で極大 值を示し, 再び減少する傾向を示した.この傾向は, オ一 トクレーブ養生下においてコンクリートの組織が結合材

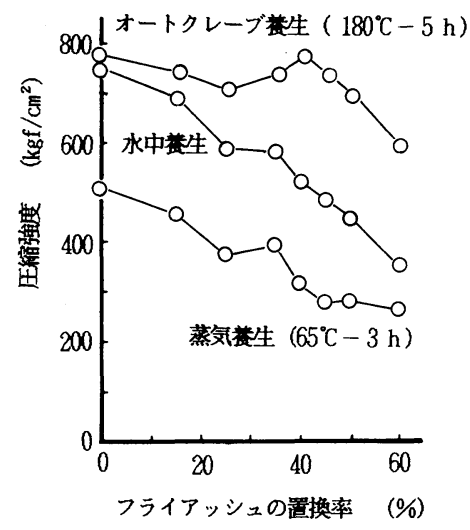

図一1 フライアッシュの置換率と各種養生下における圧縮強度 
のカルシウムとシリカのモル比 $\left(\mathrm{CaO} / \mathrm{SiO}_{2}\right)$ に影響を 受けるため ${ }^{8)}$, セメントの一部をフライアッシュで置き 換えたことによるセメント量の減少と, 高温高圧下にお けるセメントとフライアッシュの反応性などによりフラ イアッシュの置換率によってコンクリートの玨縮強度が 変化したものと考えられるが, 詳細な検討は次節で行う.

フライアッシュ $14,15,16$ を用いたコンクリートの圧 縮強度とフライアッシュの置換率との関係を図一2に示 す.この場合にも, 図一1 と同様な傾向を示し, どのフ ライアッシュを用いても置換率が $40 \%$ 程度のときに オートクレーブ養生直後の圧縮強度は極大值を示した. しかし，表一1に示したようにおのおののフライアッ シュの $\mathrm{SiO}_{2}$ 量が若干ではあるが異なるため, 極大值を 示すフライアッシュの置換率も若干異なる結果となっ た.コンクリートの単位水量とフライアッシュの置換率 の関係を図一 3 に示す. フライアッシュ 14 および 15 を 用いるとコンクリートの単位水量は置換率の増大ととも に減少する傾向を示すが, フライアッシュ 16 の場合に はコンクリートの単位水量はほとんど変化しない傾向を 示した. 図一2に示したオートクレーブ養生後のコンク リートの圧縮強度の極大值自体もフライアッシュの種類 により異なり, 図一-3の単位水量の大小と傾向が一致し ていることから，オートクレーブ養生後の圧縮強度はコ ンクリートの水結合材比にも大きく影響を受けるものと 考えられる. そこで, 各種フライアッシュを用い, 置換 率を 40 \% 一定としたコンクリートのオートクレーブ養 生直後の圧縮強度と水結合材比との関係を図一4に示 す.用いたセメントおよび空気量が異なるため, それぞ れの系列で異なる曲線となるものの, 各系列ごとに水結 合材比の増加とともにほぼ圧縮強度は低下する傾向を示 していることから，オートクレーブ養生後のコンクリー 卜の圧縮強度も水結合材比に影響を受けることが明らか となった. しかし, フライアッシュによっては, 他とは 異なった傾向を示すものもあることから，水結合材比の みならずフライアッシュの化学成分等もコンクリートの 圧縮強度に影響を及ぼすものと考えられる.

\section{（2）微細組織による検討}

コンクリートの圧縮強度に影響を及ぼす要因は配合条 件, 養生条件等数多くあるが, 本節においては, 硬化後 の微細組織の観察を行い, 図一1に示したフライアッ シュ 13 を用いたコンクリートのオートクレーブ養生後 の圧縮強度に及ぼすフライアッシュの影響について検討 を加えた。

微細組織の面から，コンクリートの圧縮強度を考えた 場合, コンクリート中のペースト部分自体の強度，すな わち, 水和生成物の形態と空隙量に圧縮強度は影響を受 ける. そこで, コンクリートと同一配合, 同一養生のセ

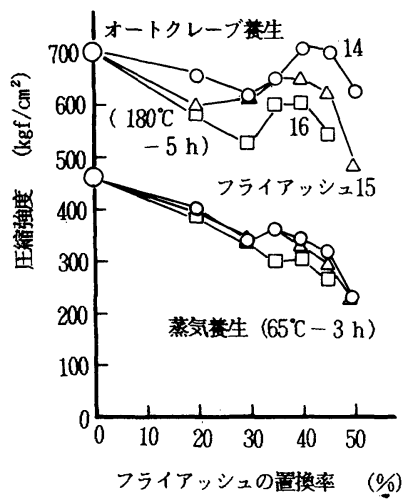

図一2 コンクリートの圧縮強度に及ぼすフライアッシュの種類 の影辢

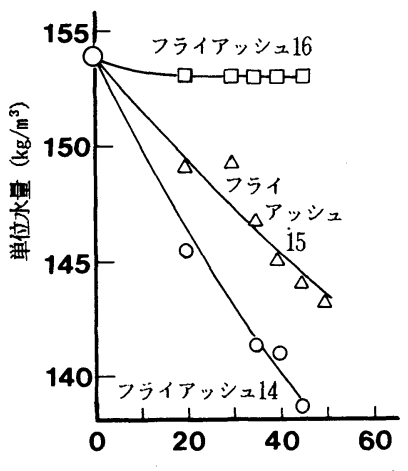

図一－フライアッシュの置換率とコンクリートの単位水量

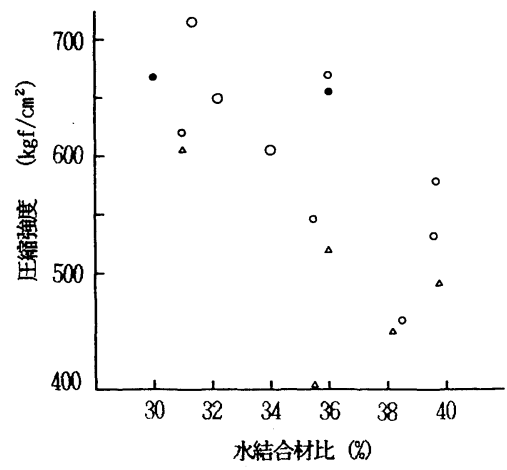

図一4 水結合材比とコンクリートの圧縮強度

メントペーストの細孔径量と細孔径分布および水和生成 物について検討した。

ペースト中の細孔に関しては，水置換法による空隙量 (見掛け気孔率)，水銀圧入法による細孔量および細孔 径分布, 窒素吸着法による比表面積を測定した。これら の試験から得られる値は，試験方法により細孔径の範囲 が限られている. 水置換法により得られた空隙量を全空 
表一3 セメントペーストの微細組織

\begin{tabular}{|c|c|c|c|c|c|}
\hline $\begin{array}{l}\text { フライアッシン } \\
\text { の置换率 }(\%)\end{array}$ & $\begin{array}{l}\text { 全空腙 } \\
(\%)\end{array}$ & $\begin{array}{l}\text { 細孔曼 } \\
\left(\mathrm{cm}^{3} / \mathrm{g}\right)\end{array}$ & $\begin{array}{l}\text { 細孔量 } \\
\left(\mathrm{cm}^{3} / \mathrm{g}\right)\end{array}$ & $\begin{array}{c}\text { 平均期扎佳 } \\
(\AA)\end{array}$ & $\begin{array}{l}\text { 比表面喽**** } \\
\left(\mathrm{m}^{2} / \mathrm{g}\right)\end{array}$ \\
\hline 0 & 34.3 & 0.096 & 0.0215 & 189 & 18.3 \\
\hline 25 & 41.7 & 0.124 & 0.0534 & 388 & 17.1 \\
\hline 40 & 42.7 & 0.121 & 0.0219 & 204 & 15.1 \\
\hline 60 & 43.0 & 0.106 & 0.0239 & 158 & 6.06 \\
\hline
\end{tabular}

* : 水银压入洼による䈥孔

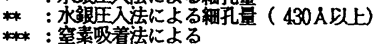

隙量と仮定し, 水銀圧入法によって得られる細孔径は $75 \AA 275000 \AA$ の範囲にある. 表一3にこれらの試験に よって得られた試験值を示す.ただし，平均細孔径とは， 水銀圧入法により得られた細孔量の累積曲線において容 積が 50 \% の場合に相当する細孔径を表わす。

表一3より，全空隙はフライアッシュを混和すること により若干ではあるが増大している. 平均細孔径を比較 すると，セメントの $25 \%$ をフライアッシュで置き換え た場合に平均細孔径が増大するが，置換率の増加ととも に平均細孔径は減少している。 また, Mindess ${ }^{9)}$, Bentur $^{10)}$ によると, カルシウムシリケート水和物の強 度は細孔径が $300 \AA$ から $500 \AA$ 程度以上の細孔量に特 に影響を受けることから，水銀圧入法により得られた細 孔量のうち細孔径が $430 \AA$ 以上の細孔量について検討 を加えたが, 置換率が $25 \%$ においてこれらの細孔量が 著しく増大しているのが認められた。一方, 窒素吸着法 による比表面積は，置換率が $60 \%$ の場合著しく小さな 值を示したことから，セメントの $60 \%$ をフライアッ シュで置き換えたことにより水和生成物量が著しく減少 したことを示している.

粉末 X 線回折によって水和物を同定した結果, すべ ての置換率において水酸化カルシウム，カルシウムシリ ケート水和物およびハイドロガーネットが同定されるも のの, 置換率が $25 \%$ の場合, 強度の低い $\alpha-\mathrm{C}_{2} \mathrm{SH}$ (強 度が $\left.2 \sim 3 \mathrm{kgf} / \mathrm{cm}^{2}\right)$ が同定された。また，置換率が 40 $\%$ および $60 \%$ において強度の高いトベルモライトが同 定されたが，置換率が $40 \%$ の方がピークが鋭く大きく なっている，さらに，置換率が $60 \%$ の場合には未反応 のフライアッシュ量が多くなっている.

以上のことより, 置換率が $25 \%$ の場合には平均の細 孔径が大きくなり, 径の大きな細孔量も増加しているこ と,さらには強度が $2 \sim 3 \mathrm{kgf} / \mathrm{cm}^{2}$ 程度の $\alpha-\mathrm{C}_{2} \mathrm{SH}$ が同 定されていることから，圧縮強度が減少したものと考え られる.また，電子顕微鏡による観察によれば，置換率 が $25 \%$ では空隙中に水和物が生成していない場合が多 いのに対し, 置換率が $40 \%$ の場合空隙中に多量のトベ ルモライトが生成している，一方，置換率が $60 \%$ とな ると, 平均細孔径は小さくなるものの, 水和生成物量が
著しく少なくなるため圧縮強度が低下するものと考えら れる. 置換率が $40 \%$ の場合には, 平均細孔径の低減, 径の大きな細孔量の减少および強固な水和物の生成によ り圧縮強度が極大值を示したものと考えられる。

\section{5. フライアッシュを混和したコンクリートの} 高強度化

\section{（1）養生条件による強度の改善}

フライアッシュは高温養生が有効であることが明らか であるが，コンクリートの強度改善を目的として, 蒸気 養生およびオートクレーブ養生の養生条件を変化させ圧 縮強度について検討を加えた。

図一5 は, フライアッシュ無混和のコンクリートと図 一1で無混和と同等な圧縮強度を示したフライアッシュ 13 を $40 \%$ 混和したコンクリートの圧縮強度に及ぼす蒸 気養生後までのマチュリティー $\left(0^{\circ} \mathrm{C}\right.$ 以上の積算温度 $)$ の影響を示す. 蒸気養生における最高温度 $65^{\circ} \mathrm{C}$, 保持 時間 3 時間を基本にし (基本養生), 最高温度を $80^{\circ} \mathrm{C}$ に上昇させ，保持時間を 3 時間とした場合 (養生 I ) と， 最高温度を $65^{\circ} \mathrm{C}$ とし，養生 I と同じマチュリティーと なるように保持時間を 5.89 時間とした場合（養生 II） のコンクリートの圧縮強度について検討を加えた。なお， オートクレーブ養生はすべて最高温度 $180^{\circ} \mathrm{C}$, 保持時間 5 時間一定とした。

図一5上り, 蒸気養生直後の圧縮強度はマチュリ ティーを増大させることにより，養生 I ，養生 II とも圧 縮強度は増大し, 同じ值を示している. 特に, フライアッ シュを混和したコンクリートは圧縮強度の増加量が無混 和に比べて大きいことから，高温養生はフライアッシュ の反応性に対して有効である。しかし，最高温度を高く した養生 I の場合，オートクレーブ養生直後の圧縮強度 は, フライアッシュ無混和のコンクリートでは, 基本養

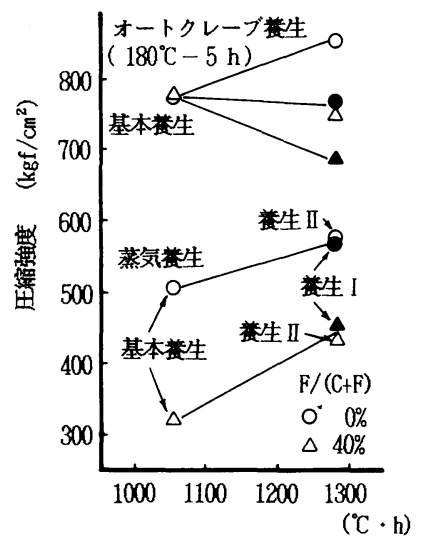

蒸気兴生までのマチュリティー

図一5 蒸気養生条件がコンクリートの圧縮強度に及ぼす影暨 
生とほぼ同じ值を示したが, フライアッシュを混和した コンクリートは, 基本養生のコンクリートに比べ小さな 值を示した．養生 I の場合，水銀圧入法によって得られ た細孔径分布は基本養生のものとは異なり，430 ̊上 の比較的大きな径の細孔量が増加している.したがって, 蒸気養生の最高温度を高くしてマチュリティーを増大さ せた場合には，その後のフライアッシュの水熱反応は悪 影響を受けていると考えられる．それに対し，保持時間 を長くしてマチュリティーを増大させた養生 II $の$ 場合に は, オートクレーブ養生後の圧縮強度はフライアッシュ を混和しても低下しない，したがって，蒸気養生後の圧 縮強度を増大させる方法として, 養生時間を長くしてマ チュリティーを増大させることは，1つの有効な方法で ある.

オートクレーブ養生温度と压縮強度との関係を図一6 に示す.この場合, 蒸気養生条件は最高温度 $65^{\circ} \mathrm{C}$, 保 持時間 3 時間一定とした.フライアッシュ無混和の場合, $190^{\circ} \mathrm{C}$ までは養生温度の増加とともに圧縮強度は増大す るが, $210^{\circ} \mathrm{C}$ では $190^{\circ} \mathrm{C}$ に比べ圧縮強度は低下している. 粉末 $\mathrm{X}$ 線回折によると, 各養生温度において水酸化力 ルシウム，カルシウムシリケート水和物および八イドロ ガーネットが同定され，養生温度が $190^{\circ} \mathrm{C}$ の場合には 強度の高いトベルモライトが, $210^{\circ} \mathrm{C}$ の場合には強度の 低い $\alpha-\mathrm{C}_{2} \mathrm{SH}$ が同定されている. 養生温度が $210^{\circ} \mathrm{C}$ の 場合には水銀圧入法によって得られた全細孔のみなら ず，430 § 以上の比較的大きな径の細孔量も増大してい ることから，圧縮強度が低下したものと考えられる。

フライアッシュを $40 \%$ 置換した場合, 養生温度を $150^{\circ} \mathrm{C}$ とすると，無混和に比べ $100 \mathrm{kgf} / \mathrm{cm}^{2}$ 以上も圧縮 強度は低下しているが, $210^{\circ} \mathrm{C}$ まで養生温度の増加とと もに圧縮強度は増加している. 粉末 X 線回折によると, 養生温度が $150^{\circ} \mathrm{C}$ の場合においてもトベルモライトは 同定されているが, 養生温度の増加とともにトベルモラ イトのピークが大きく，鋭くなっていることより，フラ イアッシュの水熱反応が活発になっていることが認めら れた。電子顕微鏡を用い空隙中に生成した水和生成物を 観察したが, $150^{\circ} \mathrm{C}$ ではほとんぞ水和生成物が観察され ず， $180^{\circ} \mathrm{C}$ 以上ではタンザク状の水和生成物が観察され た。このようにフライアッシュを混和したコンクリート の圧縮強度に及ぼすオートクレーブ養生時の養生温度の 影響が大きいことが明らかとなった。

さらに, 形状が覀いため圧縮強度の低下が認められた フライアッシュ 16 を用いたコンクリートの圧縮強度の 改善方法を目的として，同様の検討を加えた。

図一7にコンクリートの圧縮強度に及ぼす各養生条件 の影響を示す.フライアッシュ 16 の場合には，図一5 で示したフライアッシュ 13 と同様に蒸気養生時の保持

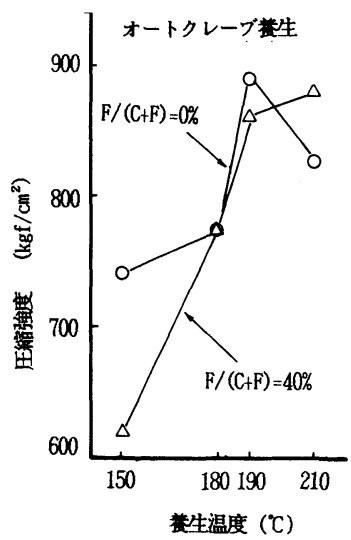

図一6 オートクレーブ養生温度の影

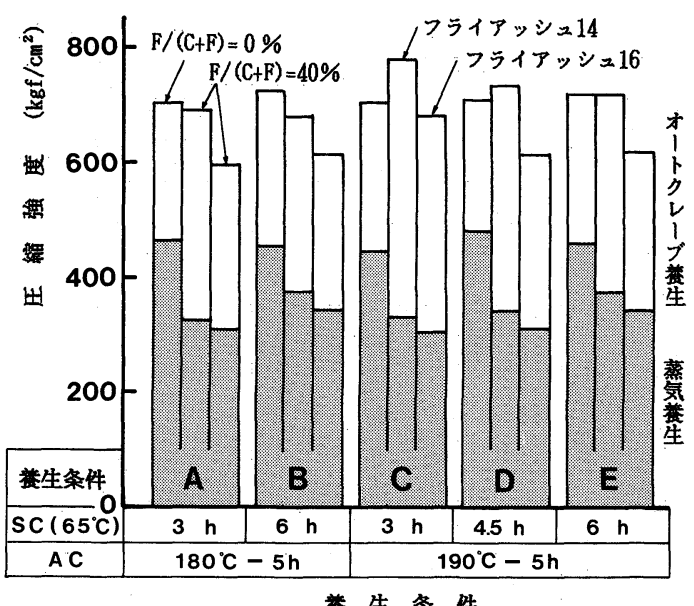

図一7＼cjkstart養生条件とコンクリートの圧縮強度

時間を増大させることにより (養生 B), 蒸気養生直後 の圧縮強度は増大するものの, オートクレーブ養生直後 の圧縮強度は基本養生 (養生 A) とほぼ同じ值を示した。 一方, 蒸気養生の最高温度を $65^{\circ} \mathrm{C}$, 保持時間を 3 時間 とし, オートクレーブ養生時の養生温度を $190^{\circ} \mathrm{C}$ と増 大させる (養生 C) と, オートクレーブ養生直後の圧 縮強度は著しく増大し, フライアッシュ 16 を用いても フライアッシュ無混和とほぼ同じ值を示した。特にフラ イアッシュ 14 のように減水効果を示すフライアッシュ を用いた場合には，フライアッシュ無混和よりも大きな 圧縮強度を示した。

しかし, 蒸気養生直後の圧縮強度の増大を目的とし, 蒸気養生時の養生時間を長くすること（養生 $\mathrm{D}$ および 養生 E) はオートクレーブ養生直後の圧縮強度の増加 にはつながらず，オートクレーブ養生時の最高温度を $190^{\circ} \mathrm{C}$ に上昇させても，コンクリートの圧縮強度は基本 養生（養生 A）とほぼ同じ値を示した。すなわち，オー 


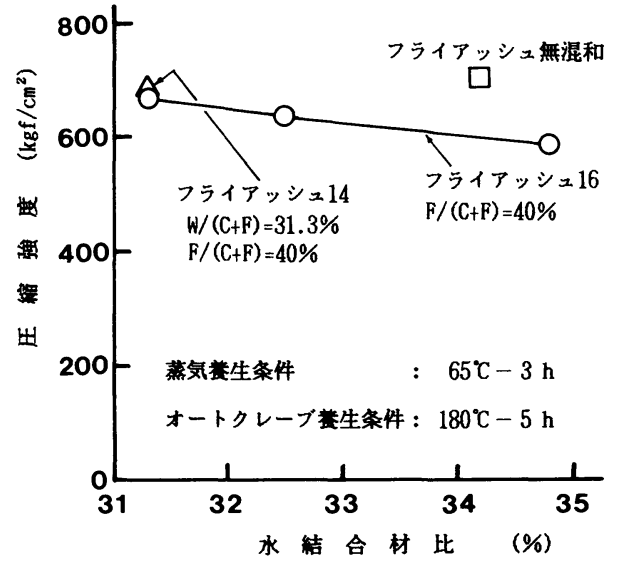

図一8 水結合材比とコンクリートの圧縮強度

トクレーブ養生直後の圧縮強度の増大を目的とし, オー トクレーブ養生の最高温度を増加させる場合には, 蒸気 養生条件としては最高温度 $65^{\circ} \mathrm{C}$, 保持時間 3 時間程度 が適当である.

このように，フライアッシュ 16 のように減水効果の 少ないフライアッシュを用いた場合にも, 養生条件を適 切に選定することにより，フライアッシュ無混和とほぼ 同じ圧縮強度を示すことが明らかとなった。

\section{（2）水結合材比の低隇効果}

4. においてコンクリートの圧縮強度に及ぼす影響と して水結合材比の影響が大きいことを述べた。 そこで, フライアッシュ 16 を用いて, 水結合材比の低減による コンクリートの高強度化について検討を加えた.

図一8は，水結合材比とフライアッシュを混和したコ ンクリートの圧縮強度との関係を示す. 水結合材比は高 性能減水剤の添加量を増大することにより低減した。た だし，高性能減水剤を多量に添加した場合，セメントの 凝結が遅延されるため, 蒸気養生までの前置き時間を 12 時間とした.

図一3 および図一 8 より，フライアッシュ 16 を用いる と減水効果がほとんどなく, 高性能減水剂を無混和と同 量用いた場合には，圧縮強度も無混和に比べ低下してい る. しかし, 高性能減水剤を多量に添加し, 水結合材比 を低減することにより，圧縮強度は増大しており，フラ イアッシュ 14 を用いたコンクリートと同じ水結合材比 (31.3\%) にした場合には，フライアッシュ 14 の場合 とほぼ同じ圧縮強度を示し, かつフライアッシュ無混和 とほぼ同じ圧縮強度を示した.

このように，水結合材比を低減することにより，圧縮 強度は増大し, 水結合材比が同じであれば圧縮強度はほ ぼ同じ值を示すことから，減水効果の小さいフライアッ シュでも高性能減水剤の多量添加により, 減水効果の大

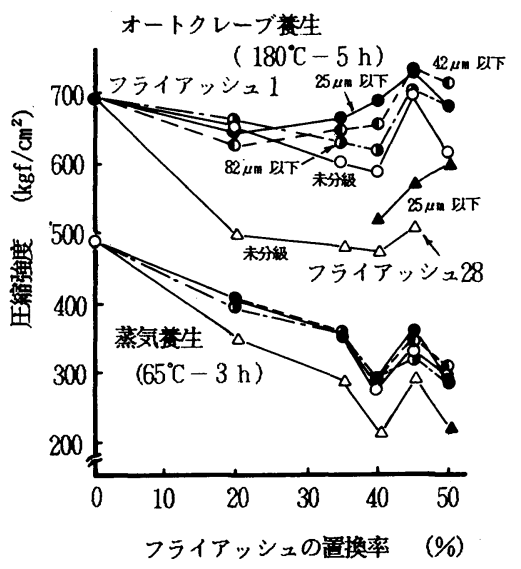

図一9 フライアッシュの置換率とモルタルの圧縮強度

きなフライアッシュと同等の水結合材比が得られ, 所要 の強度が得られることが明らかとなった。

（3） 分級したフライアッシュの利用

3.においてある粒径以下に分級したフライアッシュ は, 粒子形状, 化学成分の改善等の利点を有しているた め,これらの分級したフライアッシュを混和したモルタ ルの高温養生下における王縮強度特性について検討を加 えた. 用いたフライアッシュはフライアッシュ 1 および 28 であり，ふるいにより粒径 $25 \mu \mathrm{m}, 42 \mu \mathrm{m}, 82 \mu \mathrm{m}$ 以 下に分級したフライアッシュを用いた。

各ふるい目以下に分級したフライアッシュを混和する と, モルタルの単位水量は若干ではあるが未分級のフラ イアッシュを用いた場合に比べ減少している.これは,

3. で述べたように，分級することにより球形粒子の割 合が多くなることから減水効果が増大したものと考えら れるが, 分級したフライアッシュの粒径による単位水量 の差はほとんど認められない.

図一9に，各フライアッシュを用いたモルタルの圧縮 強度と置換率との関係を示す. 4. で用いたコンクリー

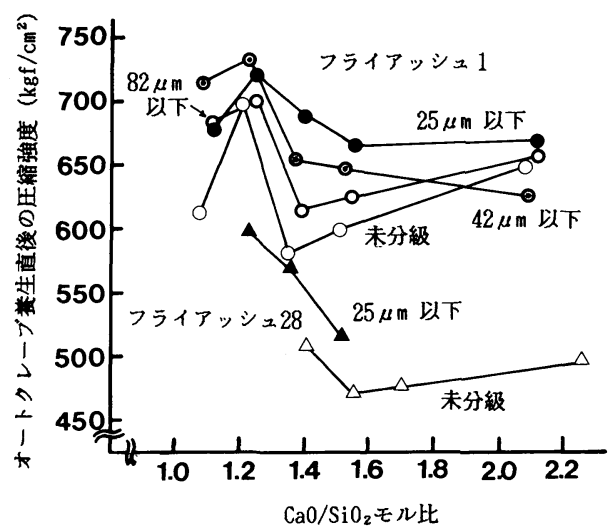

図一10 $\mathrm{CaO} / \mathrm{SiO}_{2}$ モル比とコンクリートの圧縮強度 
トの場合と同様に, ビのフライアッシュを用いた場合に も置換率が $20 \%$ 前後で圧縮強度がいったん低下する が, $45 \%$ 程度で極大值を示し，その後減少する傾向を 示した. ある粒径以下に分級したフライアッシュは未分 級のフライアッシュに比ベモルタルの圧縮強度は増大す る傾向を示し, 粒径が小さいほど若干ではあるが圧縮強 度は大きくなっている.オートクレーブ養生直後の圧縮 強度は $\mathrm{CaO} / \mathrm{SiO}_{2}$ モル比に大きく影響を受けることか ら, 両者の関係について検討を加えると, 図一10に示 すように分級しても $\mathrm{SiO}_{2}, \mathrm{CaO}$ ともに大きな差は生じ ないため，分級，未分級にかかわらず $\mathrm{CaO} / \mathrm{SiO}_{2}$ モル 比が 1.2 1.3 の範囲で圧縮強度はピークを示している. 粉末 X 線回折により水和生成物を同定したが，分級し た場合にはトベルモライトのピークが若干鋭く大きく なっている．このように，ある粒径以下に分級したフラ イアッシュは, 減水効果と化学成分の改善を有すること からコンクリート用混和材としての適用性に優れてい る.

\section{6. 高温養生下におけるクリープ特性}

前述のように，セメントの $40 \%$ 程度を減水効果の大 きい良質のフライアッシュで置き換えたコンクリート は，オートクレーブ養生を行うことによりフライアッ シュ無混和とほぼ同じ圧縮強度を示すことが明らかと なった. しかし, 蒸気養生直後の圧縮強度は無混和に比 ベ低下するため，オートクレーブ養生を行う PCパイ ル等への適用を考えた場合; オートクレーブ養生中のク リープ特性について検討を加える必要がある.

フライアッシュ 14 を用いたコンクリートのオートク レーブ養生中のクリープひずみを压縮強度とともに図一 11 に示す.オートクレーブ養生前後のひずみ変化はコ ンタクトゲージを用いて測定した。 $\phi 10 \times 20 \mathrm{~cm}$ の円筒 形供試体を用い，蒸気養生後 PC 鋼棒によりコンクリー トに $80 \mathrm{kgf} / \mathrm{cm}^{2}$ のプレストレスを導入し, オートクレー ブ養生を行った。

フライアッシュを混和することにより, 蒸気養生直後 の圧縮強度は置換率の増加とともに減少するものの, オートクレーブ養生直後の圧縮強度は 5. で述べたのよ 同様に $40 \%$ で極大值を示している.オートクレーブ養 生中のクリープもオートクレーブ養生直後の圧縮強度に 対応し, 蒸気養生直後の圧縮強度の低下にもかかわらず, 置換率 $40 \%$ で極小值を示し，フライアッシュ無混和と ほぼ同じ値を示した。このことから，クリープひずみは オートクレーブ養生直後の圧縮強度に大きく影響を受け ていると推察される。したがって，セメントの $40 \%$ を フライアッシュで置き換え，オートクレーブ養生を行っ たコンクリートは，圧縮強度だけでなく体積変化の低減

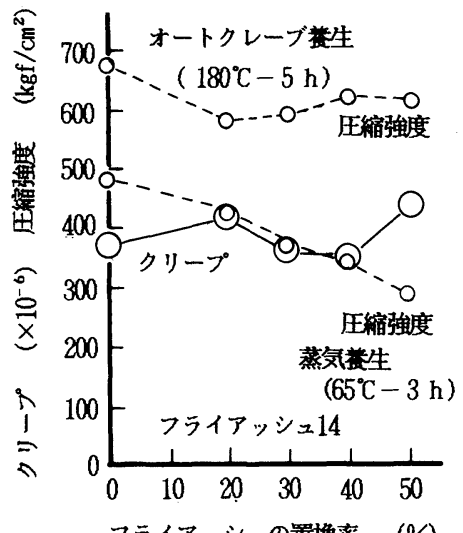

図一11 オートクレーブ養生中のクリープひずみ

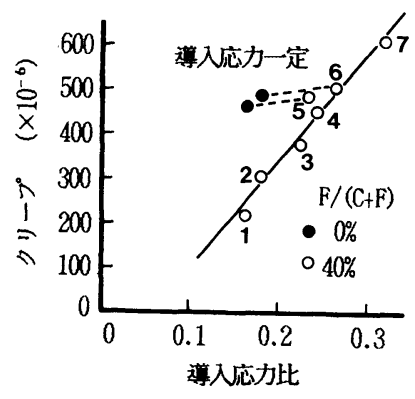

図一12 弾入応力比とクリープ

に関しても有効であることが明らかとなった。

プレストレス導入応力比（蒸気養生直後の圧縮強度に 対する導入応力の比）とフライアッシュを $40 \%$ 混和し たコンクリートのオートクレーブ養生中のクリープひず みとの関係を図一12 に示す．この場合，フライアッシュ の種類（フライアッシュ14 [図中の記号 1 6] および 16 [同 7]）および蒸気養生条件の違いによる応力導入 時の圧縮強度の変化と導入応力の変化によって導入応力 比を変化させるとともにオートクレーブ養生条件も変化 させた．フライアッシュを $40 \%$ 混和したコンクリート においても導入応力比の増加とともにクリープひずみは 直線的に増加しており，図一11で示したように，同一 応力を導入した場合, 導入時の圧縮強度が低いにもかか わらずクリープひずみが無混和とほぼ同じことから，同 一導入応力比でクリープひずみを比較した場合，フライ アッシュを 40 \% 混和したコンクリートの方がクリープ ひずみが小さな値を示した。さうに，図中点線で結んで ある点は，導入応力を同一にした供試体を表わすが，上 述のようにフライアッシュを混和すると蒸気養生直後の 圧縮強度は減少するが, その後オートクレーブ養生を行 うことにより圧縮強度は無混和とほぼ同程度となること から，導入応力を同一にした場合，オートクレーブ養生 
中のクリープひずみは無混和に比べ若干大きくなる程度 であった。

オートクレーブ養生における養生温度の影響について も検討を加えたが，オートクレーブ養生の養生温度を $180^{\circ} \mathrm{C}$ から $190^{\circ} \mathrm{C}$ に上昇させても, 養生中のクリープ ひずみは若干大きくなる程度であった。

\section{7. 結 論}

本研究は, 高温養生下においてフライアッシュコンク リートの力学特性について検討を加えるため, 近年日本 において産出した多種のフライアッシュの物理化学的性 質について検討を加えるとともに，数種のフライアッ シュを用い高温養生を行ったコンクリートの圧縮強度お よびクリープ特性に及ぼすフライアッシュの影響につい て, 蒸気養生およびオートクレーブ養生における養生条 件を変化させ，コンクリートの微細組織と関連させ検討 を加えた。

本研究により得られた結論を要約すると以下のように なる.

（1）フライアッシュの物理化学的性質は石炭の種類 により異なっている．特に所要の空気量を連行するのに 必要な $\mathrm{AE}$ 凬量に影響を及ぼす強熱減量は種類によっ て大きく異なる.

（2）フライアッシュの物理化学的性質はフライアッ シュの粒径によって異なり，粒径が小さいほざ物理化学 的性質が優れており，コンクリート用混和材として適し ている.

（3） セメントの約 $40 \%$ を減水効果の大きい良質の フライアッシュで置き換えオートクレーブ養生を行った コンクリートは, フライアッシュの高温養生下における 反応性により組織が緻密になり，さらには強固な水和物 が生成するため, フライアッシュを混和しないコンク リートの圧縮強度とほぼ同じ值を示す。

（4）フライアッシュを混和しオートクレーブ養生を 行ったコンクリートの圧縮強度改善方法としては, 蒸気 養生およびオートクレーブ養生における適切な養生条件 の選択, 高性能減水剂の多量添加による水結合材比の低 減，ふるいによりある粒径以下に分級したフライアッ シュの使用が有効である.
（5） セメントの約 $40 \%$ を減水効果の大きい良質の フライアッシュで置き換えたコンクリートのオートク レーブ養生中のクリープは, フライアッシュ無混和とほ ぼ同等である.

謝辞：本研究を行うにあたり，太斎宗一氏，東京 工業大学の研究生であった竹内徹氏（藤沢薬品工業）, 越智康介氏(株式会社花王), 矢島典明氏(電発フライアッ シュ), 東京工業大学学生であった中村武夫氏（道路公 団), 三宅且仁氏 (建設省), 和田雅行氏 (三菱重工), 嶋田久俊氏 (北海道開発局), 久保尚亮氏 (福岡県) の方々 にお世話になった。ここに深く感謝の意を表します。

\section{参 考 文 献}

1）たとえば Berry, E.E. and Malhotra, V.M. : Fly Ash in Concrete, CANMET SP-85-3, 1986.

2）資源エネルギー庁：コールノート, 資源産業新聞社, 1986.

3）長瀧・大賀・越智・中村：フライアッシュの品質とその 評価に関する研究, 第 7 回コンクリート工学年次講演会 論文集，pp. 197～200，1985.

4）長瀧・大賀・嶋田・矢島：各種フライアッシュの品質と コンクリートの流動性, セメント・コンクリート, No. 472, pp. 13 19, 1986.

5）大門 - 後藤 - 近藤：細孔容積と比表面積, 多孔材料, pp. 31 33, 1973.

6)たとえば Berry, E.E., Hemmings, R.T. and Burns, J.S. : Beneficiation of Fly Ash : An Overview of a Resource, Presentation at the 2nd Int. Conference on the Use of Fly Ash, Silica Fume, Slag and Natural Pozzolans in Concrete, 1986.

7）内川：混合セメントの水和および構造形成に及ぼす混合 材の効果（その 1)，セメント・コンクリート，No. 483, pp. 15 23, 1987.

8）須藤：オートクレーブ養生の高強度発生機構, コンクリー 卜工学, Vol. 14, No. 3, pp. 20 24, 1976.

9) Mindess, S. : The Strength and Microstructure of Autoclaved Calcium Silicates, Wissenschaftliche Zeitschrift der Hochschule fur Architektur und Bauwessen Weimar, Vol. 17, No.4, pp. 356 358, 1970.

10) Bentur, A. : Effect of Curing Temperature on the Pore Structure of Tricalcium Silicate Pastes, J. of Colloid and Interface Science, Vol.74, No.2, pp. 549 560, 1980 .

（1987.6.29・受付） 